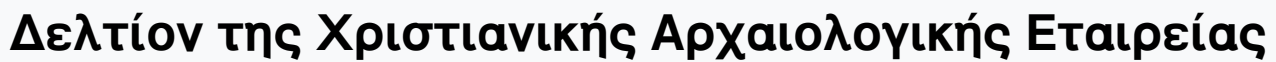

Tó 17 (1994)

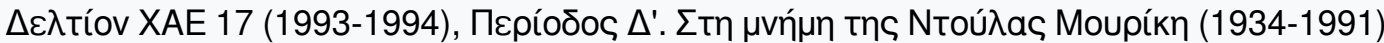

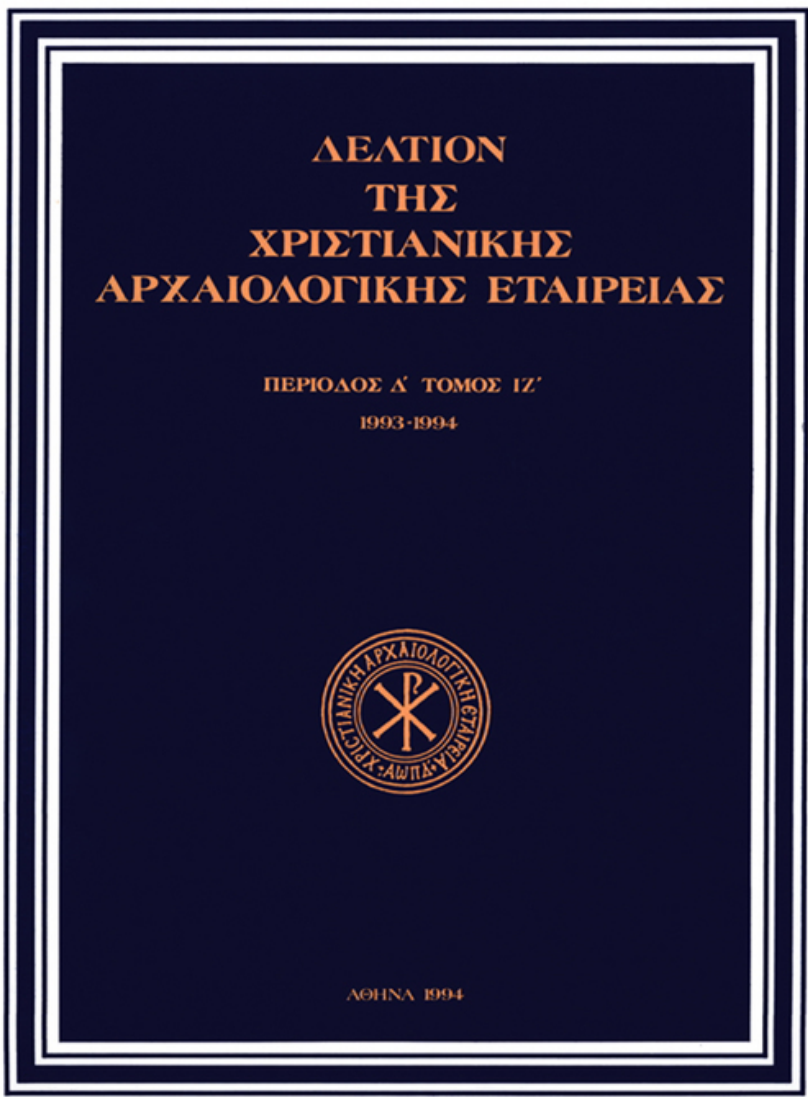

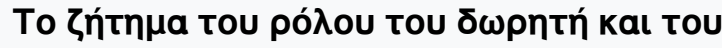

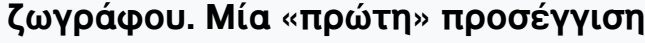

Maria PANAYOTIDI

doi: $\underline{10.12681 / \text { dchae.1099 }}$

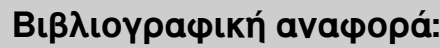

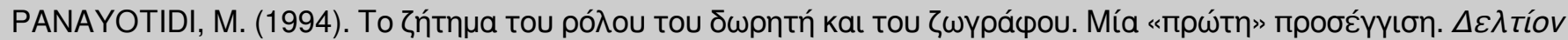

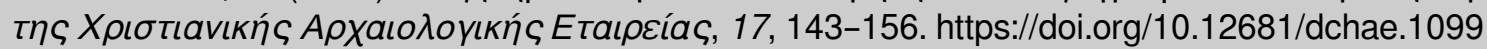




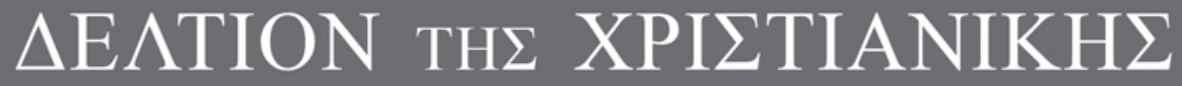 APXAIO $\Lambda$ OГIKH $\Sigma$ ETAIPEIA $\Sigma$}

The Question of the Role of the Donor and of the Painter. A Rudimentary Approach

Maria PANAYOTIDI

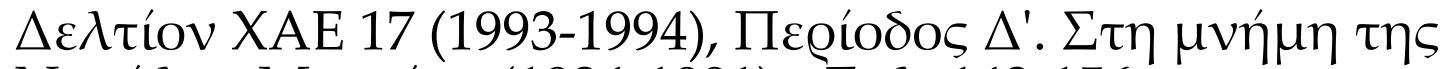

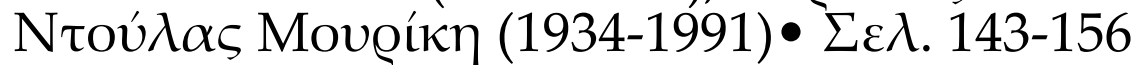

A@HNA 1994 


\section{THE QUESTION OF THE ROLE OF THE DONOR AND OF THE PAINTER A RUDIMENTARY APPROACH}

$\mathrm{T}_{\mathrm{h}}$ in producing his work, the manner, that is, in which the latter intervenes in the process of artistic creation and the degree of the painter's independence from the donor; also, the degree of recognition enjoyed by the artist, are always issues of particular interest in the study and understanding of the society of each period and of the cultural role of the various social groups. However, we have very little information on the mediaeval Byzantine society ${ }^{1}$ and, as regards the above questions, only some elements - indications rather - can for the time being be found. A general aphorism is the following wellknown passage from the Seventh Ecumenical Council of AD 787, which states that: "the painter's domain is limited to his art, whereas the disposition manifestly pertains to the holy fathers who built [the churches]"'2. Yet the painter's role in artistic creation and, by extension, his place in Byzantine society, have been very little understood $^{3}$. Thus, the examination of certain monuments permitting the formulation of observations from this angle, constitutes an attempt to pose some relevant questions and to seek certain indications.

Two groups of almost contemporary wall-paintings in Cyprus - that of the Enkleistra with the bema of the Holy Cross, in the hermitage of Saint Neophytos, near Paphos ${ }^{4}$ and that of the church of the Panagia tou Ara-

1. A. Cutle r, Art in Byzantine Society: Motive Forces of Byzantine Patronage, XVI. Internationaler Byzantinistenkongress, Akten I/2, Vienna 1981, JÖB 31/2 (1981), p. 759-787. R. Cormack, Aristocratic Patronage of the Arts in 11th- and 12th-Century Byzantium, in: M. Angold (ed.), The Byzantine Aristocracy IX to XIII Centuries, BAR International Series 221, Oxford 1984, p. 158-172. Maria Pan a yotidi, The Character of the Monumental Painting in the Tenth Century. The Question of Patronage, in: Constantine VII Porphyrogenitus and his Age, Second International Byzantine Conference (Delphi
1987), Athens 1989 , p. 285-331. Panayota Assimakopoulou-

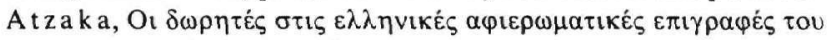

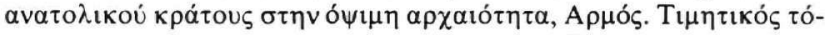

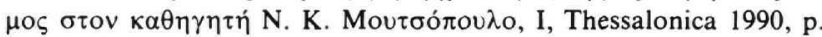
227-267. Gorda na B a bi ć, Peintures murales byzantines et de tradition byzantine (1081-1453). Possibilités et limites des analyses sociologiques, The XVIIIth International Congress of Byzantine Studies, Major Papers, Moscow 1991, p. 348ff. Sophia Kalopissi-Verti, Dedicatory Inscriptions and Donor Portraits in Thirteenth-Century Churches of Greece, TIB 5, Vienna 1992.

2. C. Magno, The Art of the Byzantine Empire 312-1453, Englewood Cliffs, N.J. 1972, p. 172.

3. R. Corm a ck, Painting after Iconoclasm, in: A. Bryer - J. Herrin (ed.), Iconoclasm, Birmingham 1977, p. 147ff., esp. 160-163. N. Oik o n o midè s, L'artiste amateur à Byzance, in: X. Barral I Altet (ed.), Artistes, artisans et production artistique au moyen âge, I. Les hommes, Paris 1986, p. 45-51. Tania Velmans, Aspects du conditionnement de l'artiste byzantin: Les commanditaires, les modèles, les doctrines, ibid., II. Commande et travail, Paris 1987, p. 79-93. Sophia Kalopissi-Verti, Painters in Late Byzantine Society. The Evidence of Church Inscriptions, CahArch 42 (1994), in press. On the Early Christian Period there is more information: Catherine Balmelle - J. P. Darmon, L'artisan-mosaïste dans l'antiquité tardive, Réflexions à partir de signatures, in: Barral I Altet (ed.), op.cit., I, 1986, p. 235-249, esp. 247-248. Panayota Assimakopoulou-

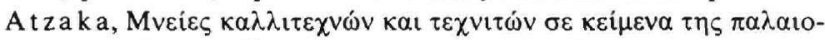

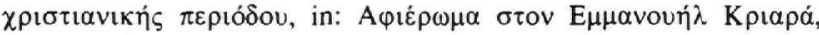

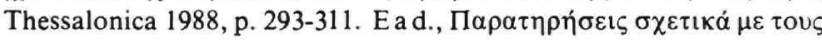

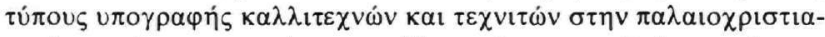

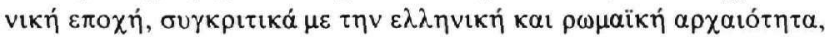

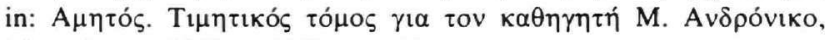
Thessalonica 1987, p. 89ff., esp. 97-98.

4. A. C. Indianos - G. H. Thomson, Wall-Paintings at St. Neo-

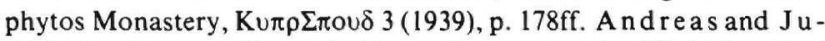
dith Stylianou, Some Problems Concerning the "Enkleistra" of St. Neophytos and its Wall-Paintings, Kv $\pi \rho \sum \pi 0 v \delta 26$ (1962), p. 131135. Eid., The Painted Churches of Cyprus, London 1985, p. 351364, pls 211, 213, 215-217. A. H. S. Megaw, Twelfth Century Frescoes in Cyprus, Actes XIIe Congrès International d'études byzantines (Ohrid 1961), III, Beograd 1964, p. 258-261, figs 12-13. C. MagnoE. J. W. Hawkins, The Hermitage of St. Neophytos and its WallPaintings, DOP 20 (1966), p. 162-185, pls 60-73, 77-109. D. C. Winfield, Reports on Work at Monagri, Lagoudera and Hagios Neophytos, Cyprus, 1969/1970, DOP 25 (1971), p. 264, pls 21-23, fig. 13. Id., Dumbarton Oaks (Harvard University) Work at Hagios Neophytos, Monagri, Perachorio and Lagoudera, 1971, 1972 and 1973 - A Final Report, RDAC 1978, p. 279-281, fig. 1, pls LXIV.3LXV.1-3. 
ka at Lagoudera ${ }^{5}$ - present an interest from this point of view, in spite of the different form of the two monuments. In the first case, that is, we are speaking of the adornment of the cell and of the bema of a hermitage, which has been almost cut out of the rock, while in the second case we have the murals of a single-aisled cruciform domed church. These two groups have not only been definitely dated, but have also preserved for us information on the identity of their patrons and even, to a certain extent, on aspects of their personalities. In the first of these groups, the name of the painter has also survived $^{6}$, and it is quite likely that the same artist was responsible for the greater part of the decoration of the second monument, as well ${ }^{7}$.

The inscription which has been preserved in the Enkleistra of the monastery of Saint Neophytos, along the upper rim of a small niche over which is depicted a monumental representation of the Deesis, with Saint Neophytos on his knees in an attitude of worship, gives the name of the painter, Theodore Apseudes, and the date as 6691 (= AD 1183), in the first Indiction ${ }^{8}$. In the church of the Panagia tou Araka, over the entrance in the north wall, the patron's inscription in three verses has been preserved, accompanying the representation of the Hagion Keramion (Holy Tile). The donor of the mural decoration of the monument, Leon Authentes, is recorded, as is the date, 6701 (= AD 1192), the month, December, and the 11th Indiction 9

Another inscription in the botton left corner of the representation of the Baptism constitutes a monk's invocation $^{10}$. In view of the fact that the examination of the letters, in comparison with those which were used in the inscriptions in the church, appears to show that the above-mentioned text is contemporary with the murals, and in view of the fact, too, that this is actually a personal invocation - that of a monk who is not the patron but who, however, is able to record his invocation in a private church - it seems very likely that the inscription refers to the artist, although his capacity and his name have not survived.

In the first monument, the patron ${ }^{11}$, a local monk, Saint Neophytos, is an important and unusual personality for the society of the time. As we know from the "Typikon" of the monastery which he founded in AD 1170, Saint Neophytos was born in AD 1134 of a rural family, in Lefkara, Cyprus, and died just after AD 1214, year in which the revised version of the above-mentioned text was copied. In his youth, Saint Neophytos travelled to the Holy Land, seeking a place in which to live as a hermit. Despite being totally illiterate up to the age of 18 and only having learnt to read and write after that age, at the monastery of Saint John Chrysostomos, at

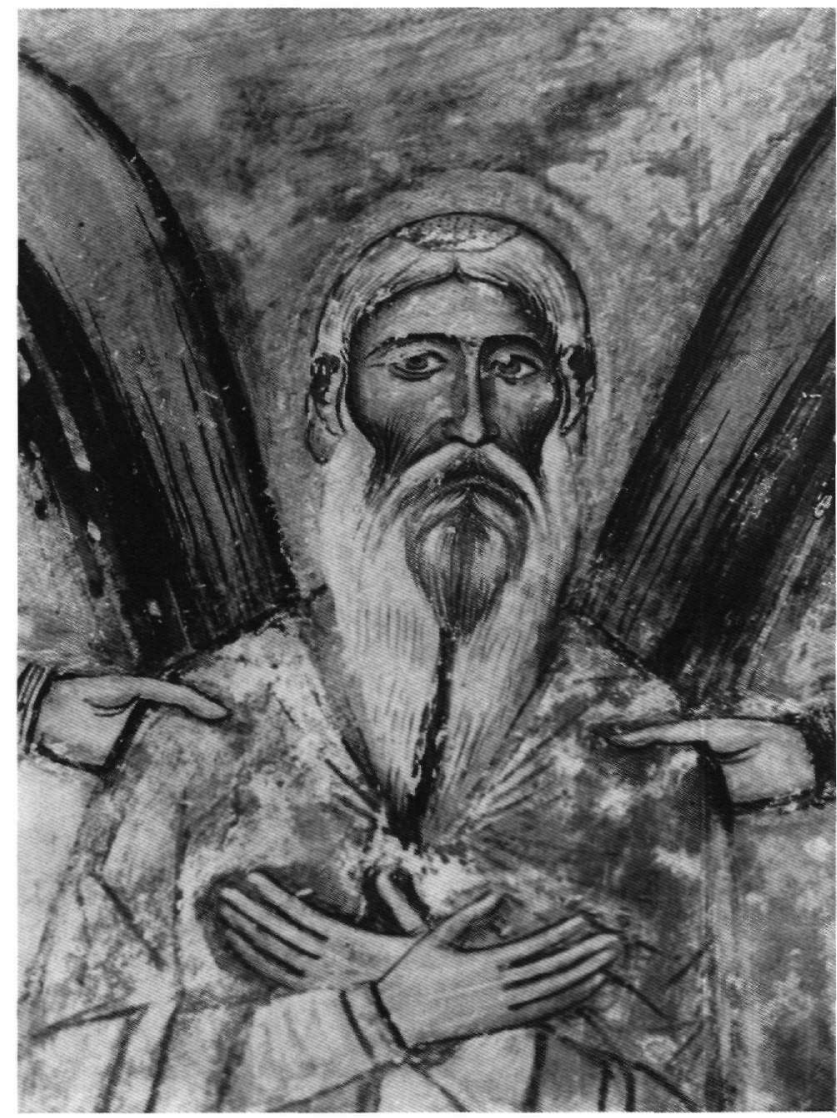

Fig. 1. Hermitage of Saint Neophytos. Saint Neophytos between the archangels, detail: Saint Neophytos.

Fig. 2. Hermitage of Saint Neophytos. Deesis, detail: Saint Neophytos.

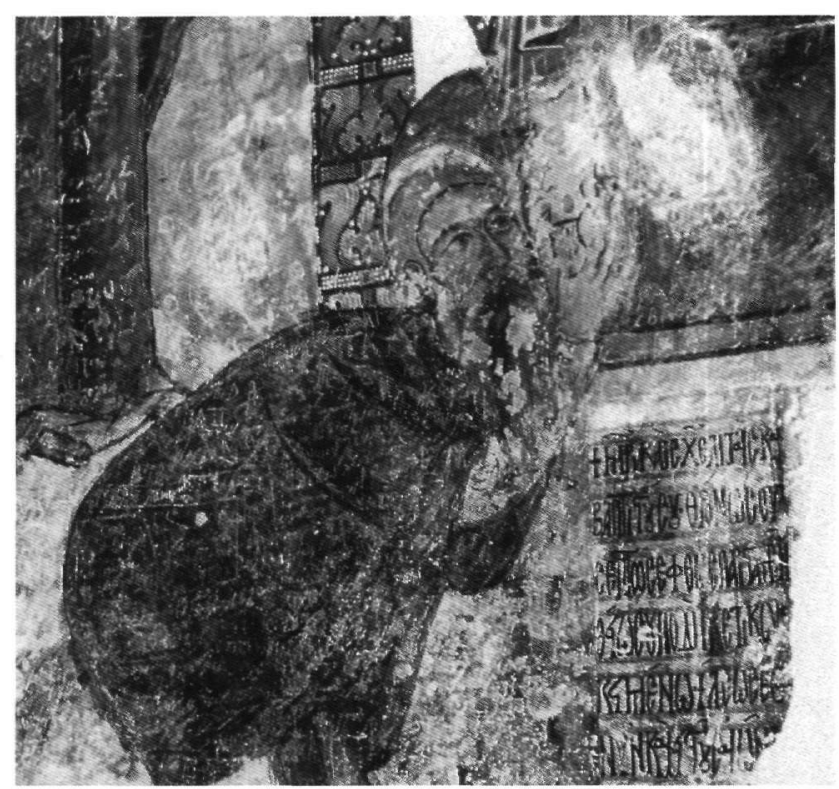


Koutsovendi, where he initially sought refuge, he left, at his death, 16 volumes of his writings, all of them on religious subjects, many of which are still unpublished. From these texts, it is apparent that he was aware of the theological issues of his time and indeed, that he took positions in the relevant discussions ${ }^{12}$. It is interesting to observe, as regards his personality, that at the monastery which he founded, he is depicted three times, in the Enkleistra and in the bema, on murals painted by Theodore Apseudes, as well as in the naos, which was decorated somewhat later, in $\mathrm{AD} 1196^{13}$.

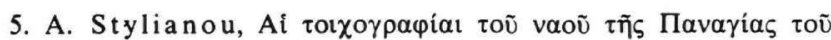

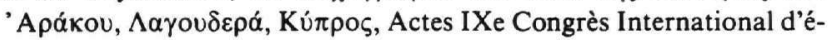
tudes byzantines (Thessalonica 1953), I, Athens 1955, p. 459-467, pls 142-157. Megaw, op.cit., p. 257-258, figs 4, 10-11, 14-15. I d., Background Architecture in the Lagoudera Frescoes, JÖB 21 (1972) (Festschrift für Otto Demus zum 70. Geburtstag), p. 195-201, figs 1-8. D. C. Winfield, The Church of the Panagia tou Arakos, Lagoudera: First Preliminary Report, 1968. With an Appendix by C. Mango, DOP 23-24 (1969-1970), p. 377-380, pls 1-7. Id., Reports, op.cit., p. 262-264, pls 10-12, 14-16. Id., Dumbarton Oaks (Harvard University) Work at Lagoudera and Monargi, 1970, RDAC 1971, p. 147-148, pls XXXV.1-XXXVI. Id., Final Report, op.cit., p. 284-287, pls LXVIII. 1-4-LXIX.1-2. Stylianou, The Painted Churches, op.cit, p. 157185 , figs $84-102$.

6. Andreas and Judith Stylianou, Donors and Dedicatory Inscriptions. Supplicants and Supplications in the Painted Churches of Cyprus, JÖBG 9 (1960), p. 99-102. A. N i col aïdès, Les Ktitors dans la peinture au XII siècle à Chypre: une remise au point, in: Artistes, artisans et production artistique au moyen âge, Université de Haute Bretagne, Rennes 1983, p. 683-686.

7. Infra, note 10 .

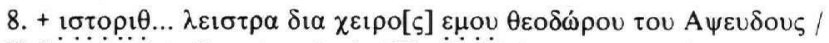

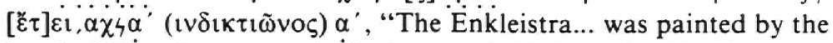
hand of Theodore Apseudes in the year 6691, indiction I", M angoHaw kins, op.cit., p. 183, Cf. also, Indianos - Thom son, op.cit., p. 187; Stylianou, op.cit. (note 6), p. 99; eid., Some Problems, op.cit. (note 4), p. 132.

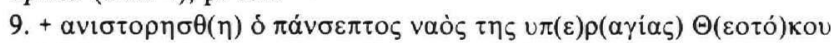

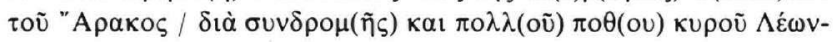

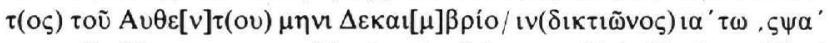

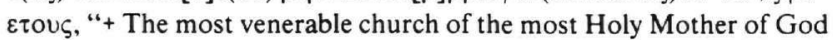
of Arakos was painted through the donation and the great desire of lord Leon the son of Authentes in the month of December, indiction XI of the year 6701". A. Stylianou, op.cit. (note 5), p. 463-464. Stylianou, op.cit. (note 6), p. 8. T. Papamastorakis, H $\sigma \eta \mu \alpha-$

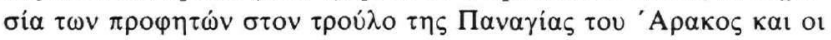

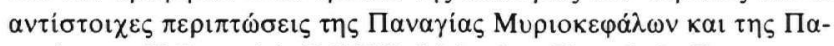

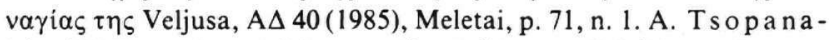

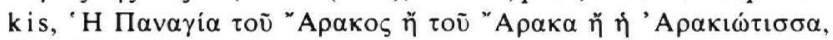
Kuл $\rho \pi 00 \delta 40$ (1986), p. 116-117.

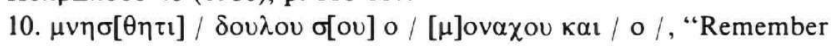
Thy slave... a monk and... o...". D. C. Winfield, Panagia tou Arakos, Lagoudera. A Guide, Nicosia s.a., p. 16-17. Annabel Jane Wharton, Art of Empire. Painting and Architecture of the Byzantine Periphery, London 1988, p. 87.

11. It is possible that the financial means for this decoration were provided by the Bishop of Paphos Basil Kinnamos who probably

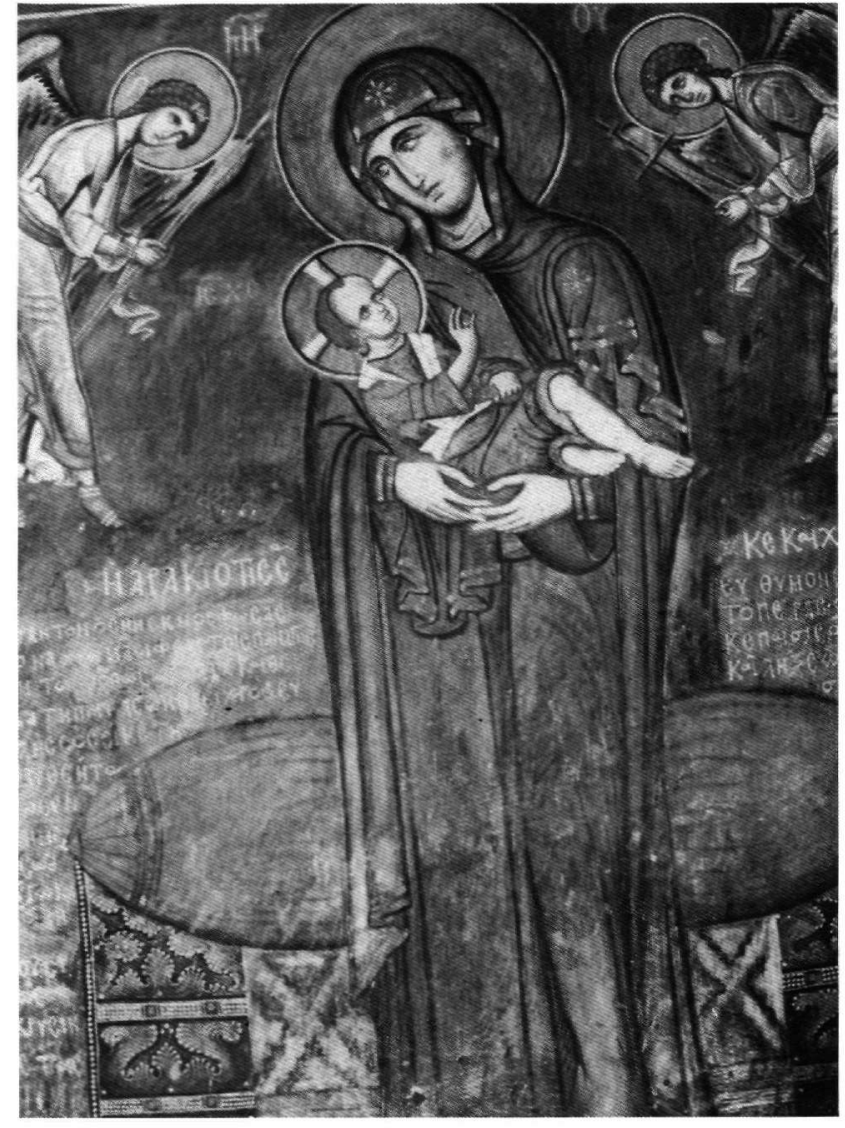

Fig. 3. Lagoudera, Panagia tou Araka. The Virgin "Arakiotissa".

invited the artist from Constantinople, $\mathrm{Mango}-\mathrm{Hawkins}$, op.cit. (note 4), p. 124. Ann Wharton Epstein, Formulas for Salvation: A Comparison of Two Byzantine Monasteries and their Founders, ChH 50 (1981), p. 397, esp. n. 59. Ea d., Art of Empire, op.cit., p. 88. R. Cormack, Writing in Gold. Byzantine Society and its Icons, London 1985 , p. $215 \mathrm{ff}$. Catia Galatariotou, The Making of a Saint. The Life, Times and Sanctification of Neophytos the Recluse, Cambridge-New York, Melbourne 1991, p. 17-18. The monastery possessed landed property. J. D a r r o u zè s, Manuscrits originaires de Chypre à la Bibliothèque Nationale de Paris, REB 8 (1950), p. 177. 12. I. Tsiknopoulos, 'O år

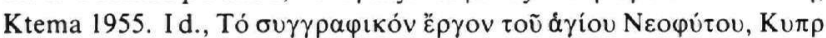

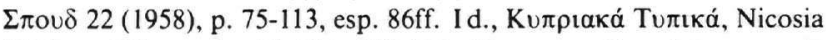
1969, p. Iff. passim, 71-104, 117-143. Mango- Hawkins, op.cit. (note 4), p. 122-132. Corm ack, op.cit. (note 11), p. 215ff., esp. 222224. G a la t a ri otou, op.cit. (note 11), p. 226ff., esp. 236, Appendix. On the theological issues of this period V. Katsaros, 'I $\omega \alpha \dot{v} v \eta \varsigma$

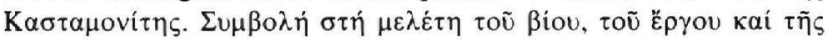

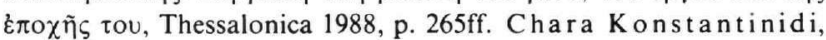

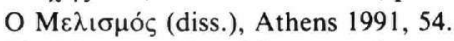

13. Mango-Hawkins, op.cit. (note 4), p. 159, 165-166, 181-182, 201 , figs $36,48,68,93-96$. Wh a r t on-E ps tein, op.cit. (note 11), p. 398-399. Galat a rioto u, op.cit., p. 130-136. On the date of the wallpaintings of the naos in the year 1196, cf. Stylianou, The Painted Churches, op.cit. (note 4), p. 354-355. 
On the murals of the bema, Saint Neophytos has been portrayed on the eastern side of the ceiling, in counterposition with the representation of the Ascension. This is a full-figure, frontal representation: Saint Neophytos, his arms crossed in front of his chest (Fig. 1), stands between the archangels Michael and Gabriel. Above his head, a distich inscription in dodecasyllabic verse has survived, expressing the holy man's supplication that he be received among the angelic hosts, by virtue of his monastic status ${ }^{14}$. In the mural of the Enkleistra, the monk is depicted kneeling, grasping the right foot of Christ with both hands (Fig. 2), in a monumental representation of the Deesis which we have mentioned above. Beside him an open inscribed scroll can be seen, containing a hexastich invocatory inscription in dodecasyllabic verse, recording his prayer for his eternal salvation through the mediation of the Holy Virgin and of Saint John the Baptist ${ }^{15}$.

Another two inscriptions which have survived in the Enkleistra are only fragmentary, but they allow us to see that they are directly related to the venerable founder of the church. The one on the eastern part of the ceiling, directly above the wall, gives us some biographical information on the founder ${ }^{16}$. The other inscription, on the face of the wall, above the tomb of the holy man, constitutes an epitaph written in the first person ${ }^{17}$.

From the above, the personal intervention of the patron, also reflecting elements of his personality, is obvious both in the representations as well as in the content of the decoration: his supplication is clearly formulated, together with his certainty of future salvation ${ }^{18}$. In the church of the Panagia tou Araka at Lagoudera, the sponsor of the painted decoration is a local nobleman, Leon Authentes who, in AD 1192, as we can see from the dedicatory inscription mentioned above - which is to say after the Latin conquest - took refuge on his land, on the slopes of Mount Troodos. According to another inscription in dodecasyllabic verse which has been preserved on the south wall of the church, on either side of the monumental representation of the Virgin "Arakiotissa" (an early type of the Virgin of the Passion) (Fig. 3) ${ }^{19}$, Leon, a local archon, quite probably the son of a notable Byzantine dignitary, prays, together with his wife and fellow-servant, for happiness during the remainder of their life, for themselves and their children, and for their final salvation ${ }^{20}$.

As has been observed from the iconographical analysis of the church's dome, the concepts which are expressed are the Incarnation, with the special significance it has for human salvation, and the Ecumenical Power of the Pantocrator. It has been considered that this semantic content of the representations of the dome, in conjunc- tion with the inscription mentioned above, express a personal and - for a man of mediaeval times - relatively anthropocentric view of the world; this is perhaps due to the high cultural level - based on a classical education - of the donor himself ${ }^{21}$. It therefore becomes apparent that the iconographical content in both monuments is inspired by the patrons' personal desires and bears a relation to their individual personalities. It has been observed, moreover, that, although the relevant reference has not been recorded - or, at any rate, preserved - the painter of the church of the Panagia tou Araka is Theodore Apseudes and that, in fact, the murals which he painted at Lagoudera represent a more mature phase, naturally enough, of the distinctly manneristic period of his art ${ }^{22}$. If the above-mentioned surviving inscription at the church of Panagia tou Araka does indeed refer to him, it would seem that at the end of his life this painter became a monk, which was not an unusual occurrence in mediaeval times ${ }^{23}$.

Indeed, if we exclude the depictions of the Virgin between the archangels (Fig. 4) and the Hierarchs in the apse of the Araka church ${ }^{24}$, which are rendered in a rela-

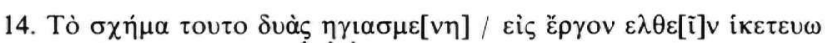
бuv $\pi$ ó $\theta[\omega]$, "I ardently implore to be enrolled among the angels by virtue of my habit". Mango-Hawkins, op.cit. (note 4), p. 166. Cf.

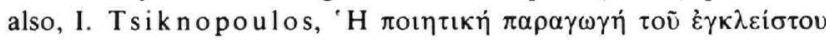

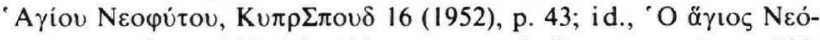

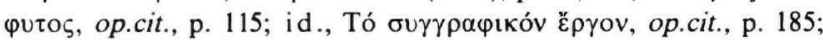
Galat ariotou, op.cit., p. 140-141.

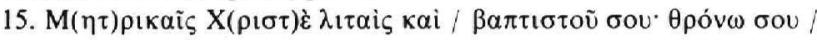

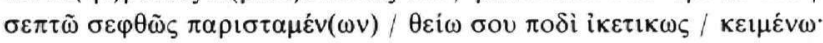

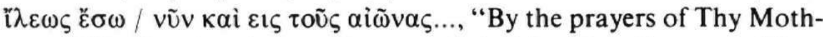
er and Thy Baptist who stand reverently by Thy Holy throne, be Thou merciful, o Christ, now and for evermore, to him that lies a suppliant at Thy divine foot". Mango-Hawkins, op.cit. (note 4), p. 181. Cf.

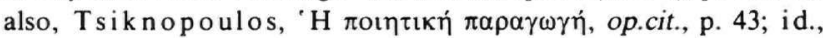

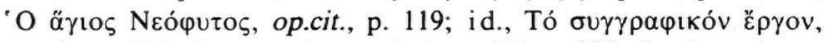
op.cit., p. 185. Corm a ck, op.cit. (note 11), p. 233. On the eschatological meaning, C. Walter, Two Notes on the Deesis, REB 26 (1968), p. 311-336. However this is a later inscription, as it partially covers the obviously longer initial inscription of which only very few letters are visible. It is difficult, though, on the basis of the comparison of the letters, to attribute this inscription to a certain phase of the decoration of the Enkleistra. Anyway it is very probable, according to the lettering, that it was written in a period when the holy man was still alive, Mango-Hawkins, op.cit., p. 182.

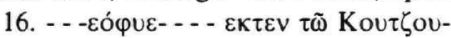

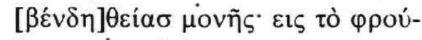

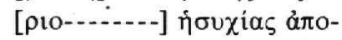

[0

(c)

-

-

Mango-Hawkins, op.cit. (note 4), p. 174. Cf. also, Indianos- 


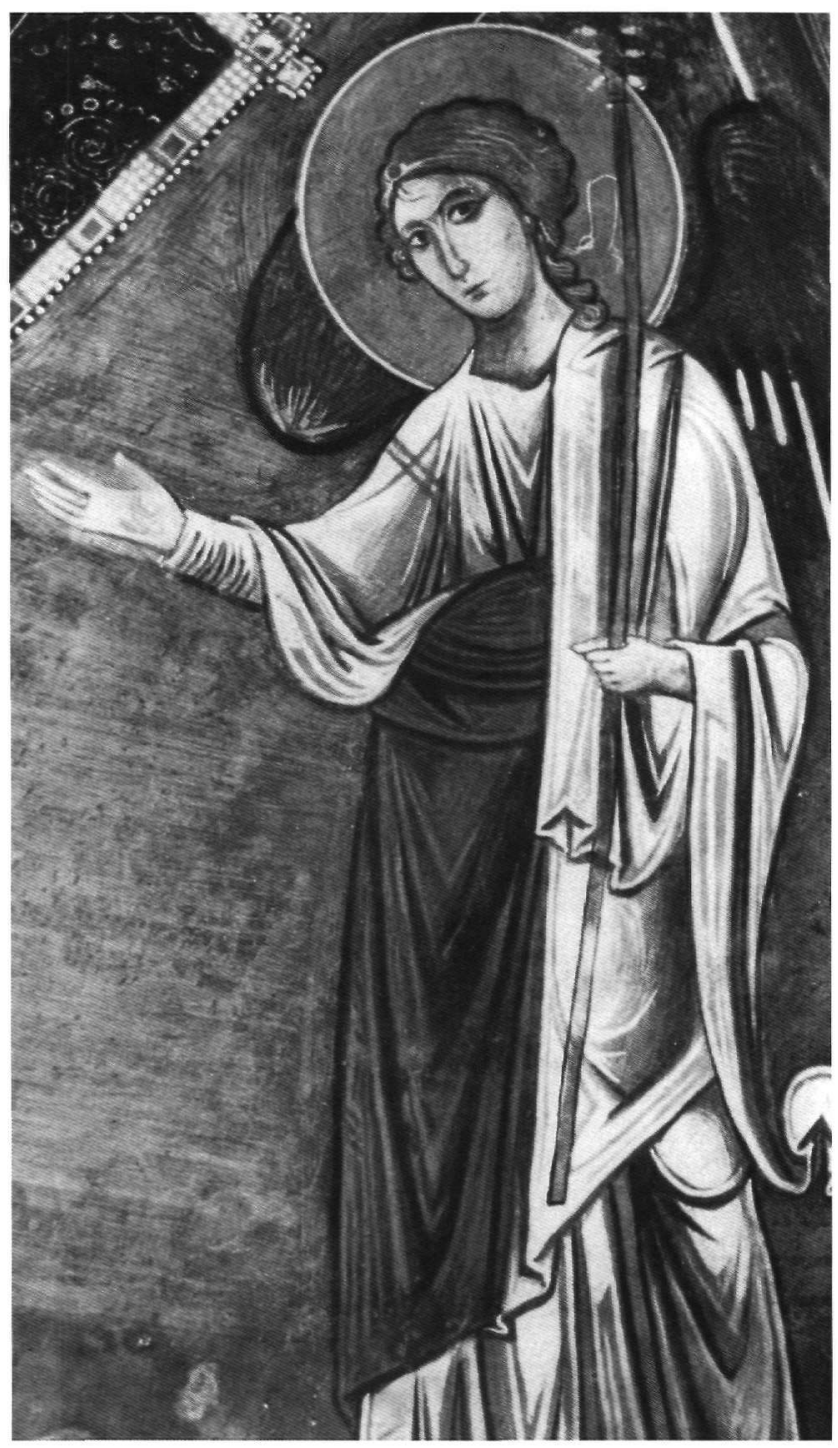

Fig. 4. Lagoudera, Panagia tou Araka. Apse, detail: the archangel Michael.

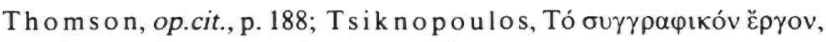
op.cit., p. 185; G a la ta ri o t o u, op.cit. (note 11), p. 144. This inscription refers to the monastery at Koutsovendi (St John Chrystostomos), where saint Neophytos started his monastic life, and to a castle, probably the castle of Paphos, where he was later arrested, in his attempt to find a passage to the mount Latmos.

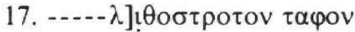

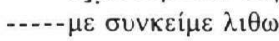

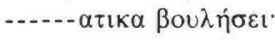

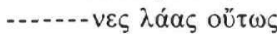

Mango-Hawkins, op.cit., p. 183, Cf. also a restoration in iambic

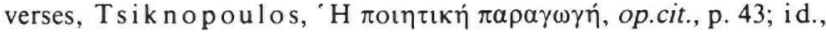

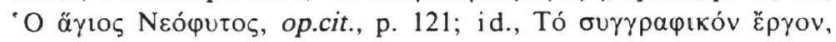
op.cit., p. 185.

18. Galatariotou, op.cit. (note 11), p. 129-130, 147.

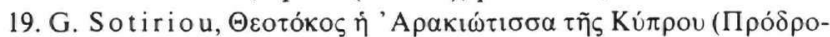

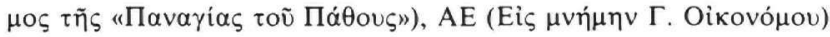

$A^{\prime}, 1953-1954$, p. $87-91$. On the interpretation of the sociological content of this representation as it relates to the calamities that befell the population of Cyprus, after the latin occupation. A. Stylia nou, Sociological Reflexions in the Painted Churches of Cyprus, XVI. Internationalen Byzantinistenkongress, Akten II/5, Vienna 1981, JÖB 32/5 (1981), p. 523-526.

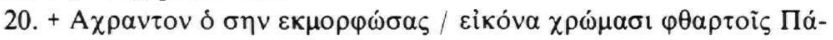

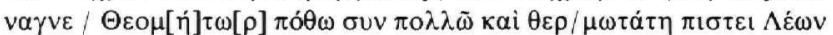

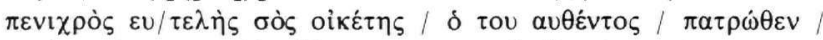

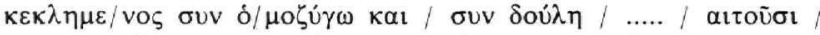

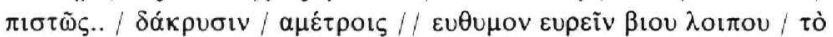

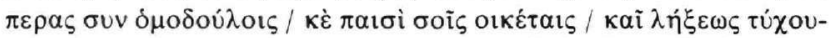

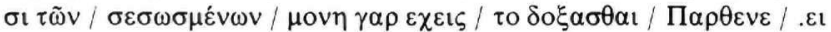

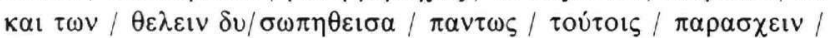
$\ldots[\sigma \omega] \tau[\eta \rho i \alpha v]$, "+ He who with great desire and warmth has portrayed in perishable colours Thine undefiled icon, o most pure Mother of God, Leon Thy poor and worthless supplicant, surnamed 'Authentes' from his father's name, along with his wife and fellow-servant, request faithfully, with countless tears, that the remainder of their life be happy, together with their fellow-servants and children, Thy supplicants, and that they may, at the end, be granted salvation, for Thou alone, o Virgin, art blessed and having taken pity, art able mercifully to give [remission of sins] to those...".

Tsopanakis, op.cit. (note 9), p. 119-124. Cf. also Sotiriou, op. cit., p. 88; Stylianou, Donors, op.cit. (note 6), p. 101-102; J. P. Sodini, Notes sur quelques inscriptions de Chypre, TM 4 (1970), p. 486; T. Pa pa mas tora kis, H $\sigma \eta \mu \alpha \sigma i \alpha \tau \omega v \pi \rho \circ \varphi \eta \tau \dot{v} v$, op.cit. (note 9), p. 89.

21. Ibid., p. 89. Tsopanakis, op.cit., p. 121. An eschatological interpretation has been supported by Tania Velmans, Quelques programmes iconographiques de coupoles chypriotes du XIIe au XVe siècle, CahArch 32 (1984), p. 137-139.

22. On stylistic similarity, Mango-Hawkins, op.cit. (note 4), p. 206. Regarding the identity of the painter, A. Papageorghiou,

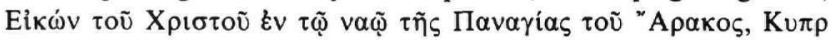

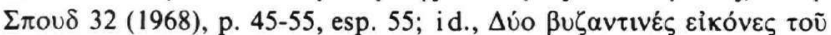
12ov aíw $\alpha$, RDAC 1976, p. 268-270; see also id., H $\alpha \mu \varphi \imath \pi \rho o ́ \sigma \omega \pi \eta$

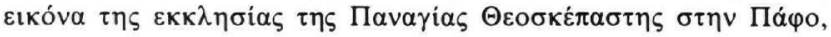

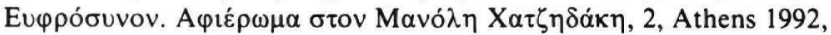
p. 488-489; Lydie Hadermann-Misguich, La peinture monumentale du XIIe siècle à Chypre, CorsiRav 32 (1985), p. 243, fig. 6. On the influence that Theodore Apseudes exercised, Annemarie Weyl Carr - L. J. Morrocco, A Byzantine Masterpiece Recovered, The Thirteenth Century Murals of Lysi, Cyprus, Austin 1991, p. $69-70,77,80$, n. 8 .

23. Whart on, Art of Empire, op.cit. (note 10), p. 88.

24. They could be attributed to a different hand and dated just before the frescoes of 1192 , ca 1190. As is normal, the decoration started from the east part of the building, St ylia nou, The Painted Churches, op.cit. (note 4) p. 175-178. Cf. with the wall-paintings of the Holy Apostles at Perachorio, 1170-1180, A. H. S. Megaw - E. J. W. $\mathrm{Hawkins}$, The Church of the Holy Apostles at Perachorio, Cyprus, and its Frescoes, DOP 16 (1962), p. 279-348, ibid., (1160-1180 AC), p. 348; Winfield, Final Report, op.cit. (note 4), p. 286; S t y lia nou, op.cit., p. 422-423, most probably 1170-1180 AC; HadermannMisguich, op.cit., p. 239-241. Cf. also with the frescoes of the church of the Archangel at Kato Lefkara, dated to the end of the 12th century, Stylianou op.cit., p. 447-450; A. Papageorghiou, H

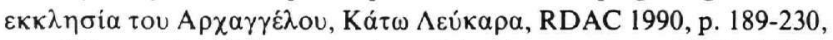
esp. 230; see also Wharton, Art of Empire, op.cit., p. 83-84; W infield, Final Report, op.cit. (note 4), p. 286; id. Panagia tou Arakos, op.cit. (note 10), p. 23-24, proposed the middle of the 12th century. 
tively simplified manner in relation to the meticulous and elaborate execution of the modelling of the flesh and the drapery of the other representations (Figs 3, 5, 6, 10, $12,14)$, the two groups - that is the murals of the Enkleistra and of the Bema of the hermitage (Figs 1, 2, $7,8,9,11,13$ ) of Saint Neophytos, which are works of Theodore Apseudes, and the greatest part of the wallpaintings of the church of the Panagia tou Araka, can very probably be attributed to the same artist.

It is not only the elegant, elongated figures with their refined features, the elaborate modelling which, however, does not allow the volumes in the rendering of the flesh to be broken up with intensity, nor the refined ornamentality and the "lyric" line which are so similar in the two groups - these, besides, are elements characteristic of a certain tendency inspired by an aristocraticdecorative mood and dating to the last two decades of the 12 th century ${ }^{25}$. It is, rather, the resemblance in the technical execution ${ }^{26}$ of the above-mentioned murals and certain details which speak in favour of this view. The rendering of the hair, for example, its outline drawn with a dark brown line, allowing the shape of the brow and temples to be clearly defined, is very similar in the two groups (Figs 9, 10). The eyes, too, in most cases, present a particular resemblance in these monuments, as the iris is painted with a light brown colour which is strongly underlined, especially on the lower rim, now with dark brown and now with dark blue tones, while, at the same time, the pupil is marked by a very fine dot, characteristics which give the gaze a luminous expression, unknown in other murals (Figs 1, 6-8, 12-14). The same close resemblance is also seen in the manner with which the brows have been drawn as, in several male figures in both these monuments, the bare brown underpainting forms an acute angle at the top, just above the bridge of the nose (Figs 1, 6,11-14). This angle tends to form a "hypsilon" in this place. Noteworthy also is the resemblance of the lettering in general, which only in the rendering of the omega - which becomes angular in the church of Panagia tou Araka - shows any substantial difference.

Since these two groups of murals in Cyprus have been executed, in the main, by the same painter, and seeing that the different social origin and education of the patrons is obvious, a comparative examination of the two, in conjunction with the evidence from the inscriptions and the writings by Saint Neophytos, might possibly contribute to the formulation of certain ideas, with regard to the questions mentioned above. However, the confined limits of an article, in this volume dedicated to the memory of Doula Mouriki - an unforgettable personality who has so greatly contributed to our knowl-

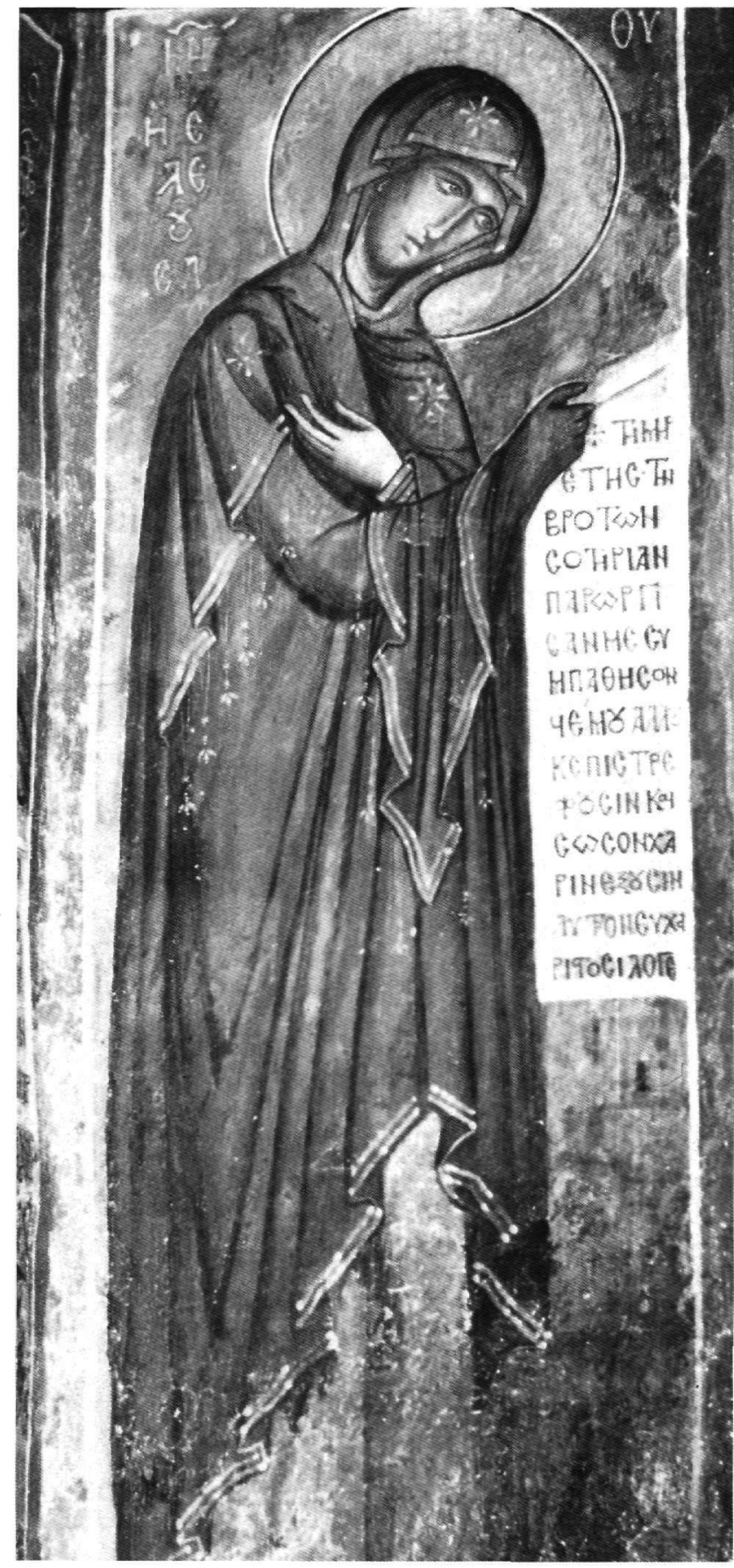

Fig. 5. Lagoudera, Panagia tou Araka. The Virgin Paraklesis.

edge of Byzantine painting, in general, and to that of Cyprus, in particular - do not permit a complete and full study of both monuments. The examination of certain common representations in these two monuments may, nevertheless, constitute an experimental startingpoint for relevant explorations.

An interesting representation, which has survived with 
variations in the two groups and which must be the work in both cases of Theodore Apseudes, is that of a type of the Virgin, whose mediatory role towards Christ is rendered very explicitly. In this representation, the Virgin addresses herself to her son and holds an open scroll, inscribed with a text in verse in the form of questions, and answers from him ${ }^{27}$. In the small niche which is above the tomb of Saint Neophytos in the Enkleistra, the Virgin is portrayed enthroned and holding the Christ Child, between two bishops, John Chrysostom and Basil the Great. In the inscribed scroll which she is holding, the text which usually accompanies the representation of the Virgin Paraklesis has been paraphrased:

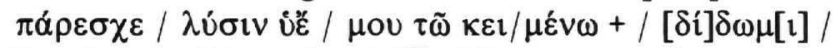
$[\kappa \alpha \mu] \varphi \theta \varepsilon i \zeta /[\sigma \alpha i \tilde{\varsigma} \lambda \iota \tau \alpha \tilde{\varsigma} \varsigma]^{28}$, "Grant, o my Son, remission to him that lies here... + I grant it, moved as I am by thy prayers". In the inscribed scrolls of the Hierarchs attending the Virgin, the texts refer to the two basic representations of the Divine Economy, regarding human salvation depicted, in the area of the tomb; they complement the composition: Chrysostom's scroll refers to the Crucifixion, and Basil's roll to the Anastasis ${ }^{29}$. The entire programme is clearly adapted to the sepulchral area which it adorns, and the inscription on the Virgin's scroll has an entirely personal character, expressing, as it does, the patron's special requests, in a space which was destined by him to remain forever closed $^{30}$. In this case, it is quite probable that Neophytos

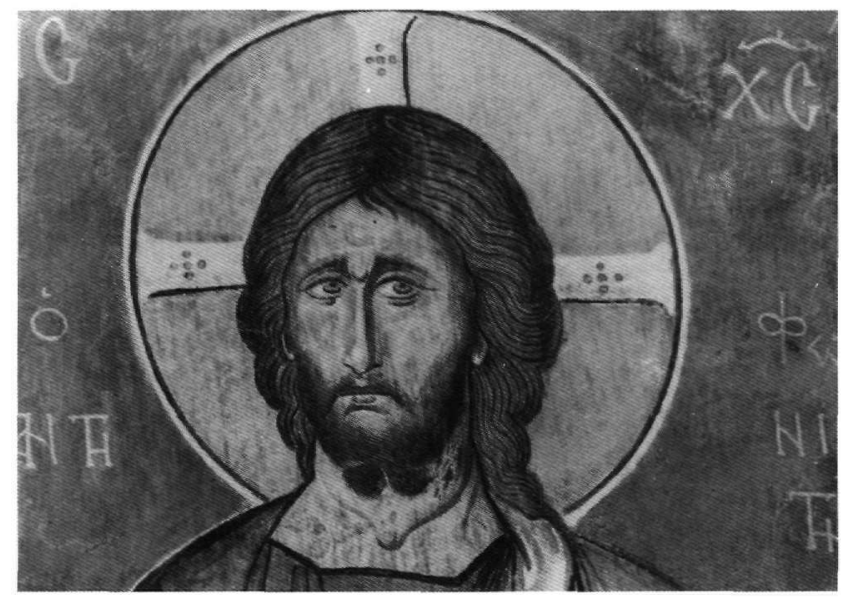

25. Maria Panayotidi, The Wall-paintings in the Church of the Virgin Kosmosoteira at Ferai (Vira) and Stylistic Trends in 12th Century Painting, First International Symposium for Thracian Studies "Byzantine Thrace", Image and Character, Komotini 1987, ByzF XIV 1 (1989), p. 466, 469-470.

26. Winfield, Reports, op.cit. (note 4), p. 262-264, esp. 264. Id., Final Report, op.cit. (note 4), p. 280-281, 285. Haderm a n n-M isguich, op.cit., p. 244-245.

27. Virgin Paraklesis (Virgin of Petition), A. Papadopoulos-Kerameus

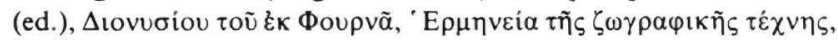

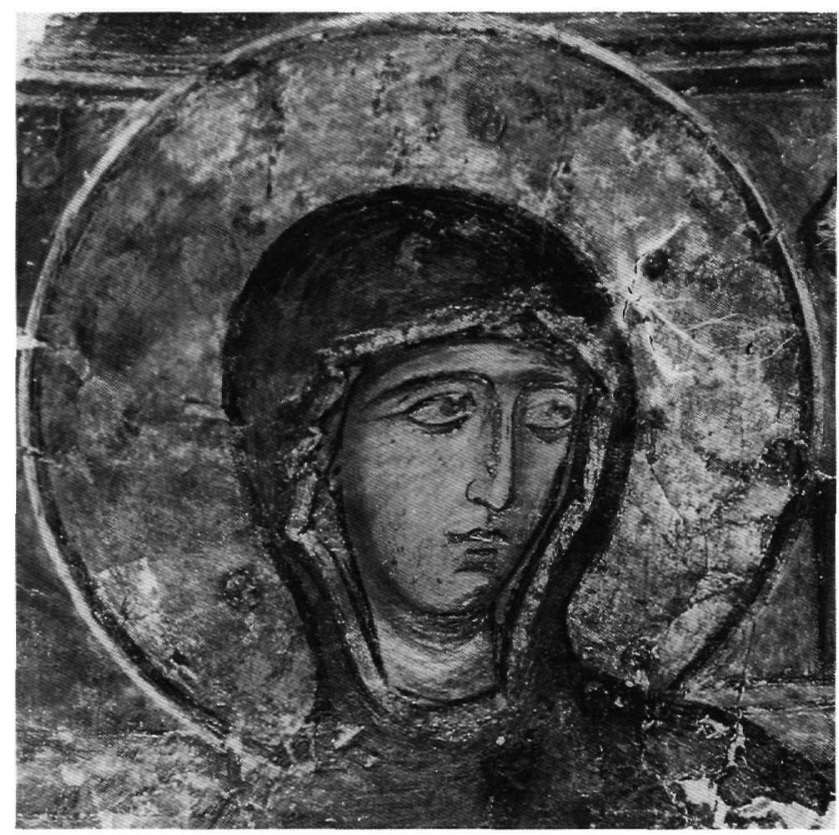

Fig. 6. Lagoudera, Panagia tou Araka. Christ Antiphonetes, detail.

Fig. 7. Hermitage of Saint Neophytos. The Annunciation, detail: head of the Virgin.

Fig. 8. Hermitage of Saint Neophytos. Deesis, detail: head of Christ.

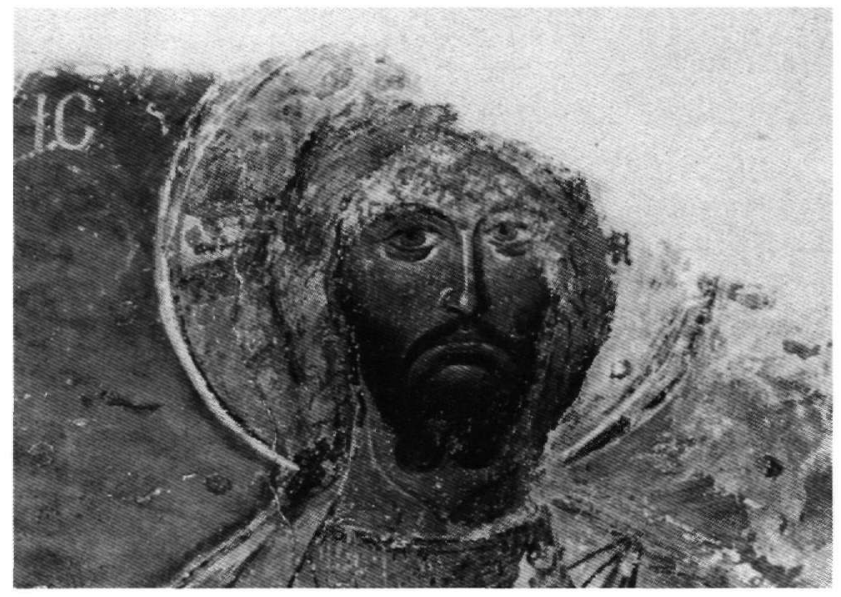

St-Petersburg 1909, p. 280. E. Cougny (ed.), Epigrammatum Anthologia Palatina III, Paris 1927, p. 423 no 125. On this iconographic type, Sirarpie Der Nersessian, Two Images of the Virgin in the Dumbarton Oaks Collection, DOP 14 (1960), p. 81-85.

28. Indianos-Thomson, op.cit. (note 4), p. 190.

29. Mango-Hawkins, op.cit. (note 4), p. 184.

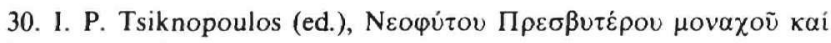

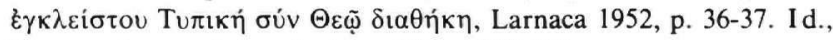

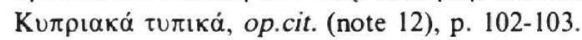




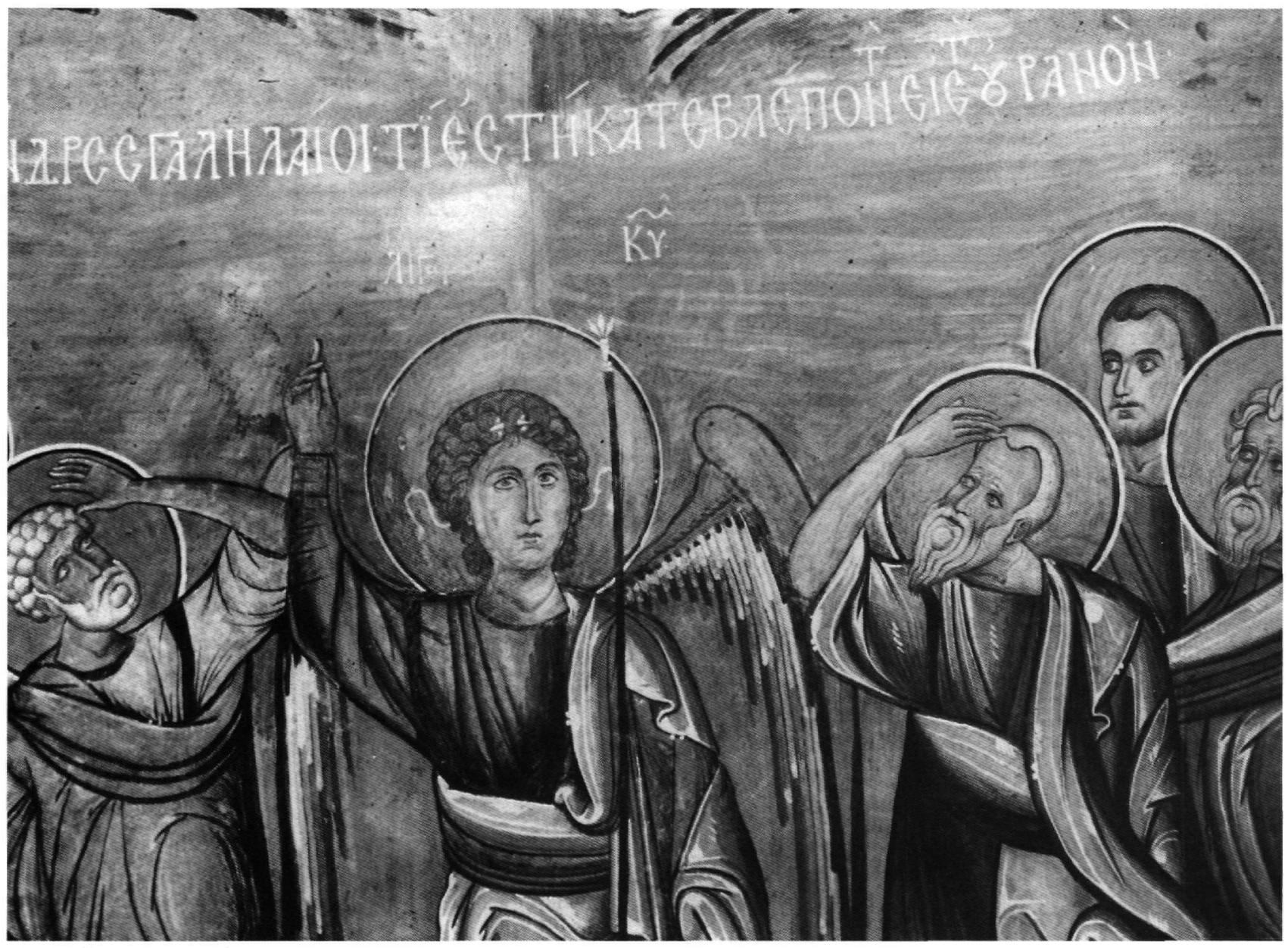

Fig. 9. Hermitage of Saint Neophytos. The Ascension, detail.

himself determined the iconographical vocabulary and dictated the text on the scroll of the Virgin and Child, according to the custom current at the time regarding the typical representation of the Panagia Paraklesis, although he adapted it to his own visions ${ }^{31}$.

On the contrary, in the church of the Panagia tou Ara$\mathrm{ka}$, the established type of representation is portrayed, in a typical position, on the western face of the northeastern pier. The interceding Virgin is depicted in threequarters view (Fig. 5), turned towards the Christ Antiphonetes, on the corresponding southeastern pier (Fig. 6), and she holds in her covered right hand an open inscribed scroll. The conventional dialogue with her Son written there is rendered, in the usual manner, by the alternation of colours in the lettering of the verses of questions and responses: $+\mathrm{T} \eta \mathrm{M \eta}(\tau \varepsilon) \rho / \varepsilon \tau \eta \zeta . \tau \eta \nu /$

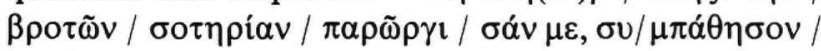

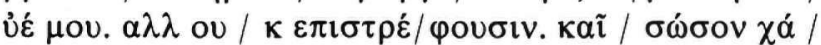

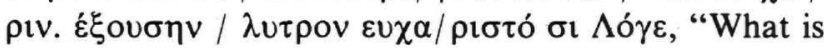

your request, Mother? - The salvation of mortals - They have angered me - Forgive them, my Son - But they do not repent - And grant them Your grace - They will be redeemed - Thank you, o Word" 32 . On either side of the Virgin the inscription has survived with the epithet, established for this type of Virgin in Cyprus Eleousa ("of Mercy") ${ }^{33}$. It has been observed that the composition was complemented by the figure of Saint John the Baptist, on whose open scroll is inscribed the wellknown Messianic verse which often accompanies his

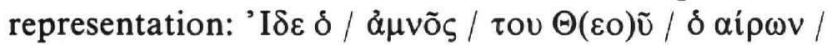

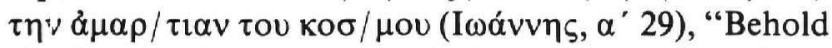
the Lamb of God, who taketh away the sins of the world" (John I, 29). Thus, a monumental Deesis is composed, as is usual in this period ${ }^{34}$.

In this way, a personal tone is given to the content of the iconographical programme, since the desire of the individual who drew it up or possibly ordered it, is clearly revealed. His request is for salvation, and Christ re- 


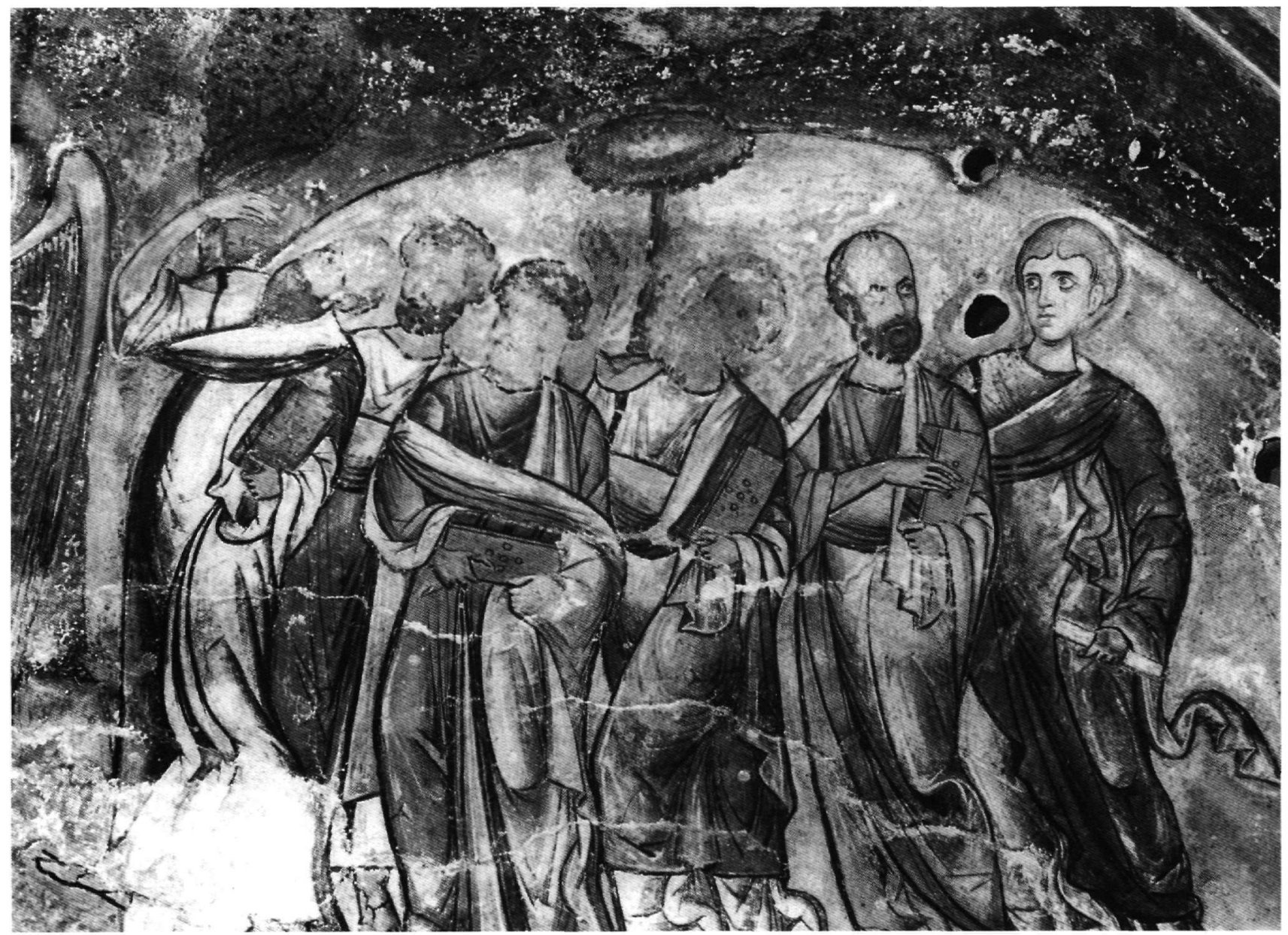

Fig. 10. Lagoudera, Panagia tou Araka. The Ascension, detail.

sponds to this. The fact, however, that this established type of representation is found either alone or in more complex depictions in other monuments of the same period, shows that at this time the theme was a favourite one, more generally, but was also usual, particularly in Cyprus. It seems quite probable, in fact, that it was one

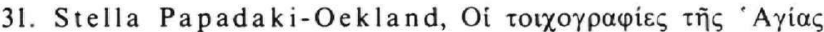

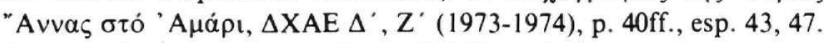
Cormack, op.cit. (note 11), p. 235-236. Galatariotou, op.cit. (note 11), p. 141

32. A. Stylianou, Ai tol $\chi 0 \gamma \rho \alpha \varphi i \alpha$, op.cit. (note 5), p. 463, pls 143.1, 154.1. Stylia nou, The Painted Churches, op.cit. (note 4), p. 159, fig. 85. Der Nersessian, op.cit., p. 81, fig. 10. Hélène Grigoriadou, Affinités iconographiques de décors peints en Chypre et

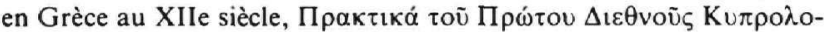
$\gamma$ үко̃ $\Sigma u v \varepsilon \delta \rho i ́ o v, \Lambda \varepsilon u \kappa \omega \sigma i ́ \alpha$ 1969, B' (1972), p. 37-38. Lydie Hadermann-Misguich, Kurbinovo. Les fresques de Saint-
Georges et la peinture byzantine du XIIe siècle, Bruxelles 1975, p. 229230 , fig. 119. On the function of the image, A. Kazhdan $-\mathrm{H}$. Maguire, Byzantine Hagiographical Texts as Sources of Art, DOP 45 (1991), p. 15-16, figs 25-26.

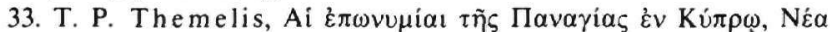

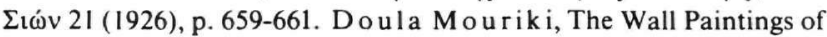
the Church of the Panagia at Moutoullas, Cyprus, in: Irmgard Hutter (ed.), Byzanz und der Westen, Studien zur Kunst des europäischen Mittelalters, Vienna 1984, p. 189-190. On a reasonable explanation, C. Walter, Further Notes on the Deesis, REB 28 (1970), p. 162-168. 34. Papadaki-Oekland, op.cit., p. 34-51. Hadermann-Misguich, op.cit., p. 230-234, esp. 233. Ea d., La peinture monumentale, op.cit. (note 22), p. 224-255, fig. 7. Jacqueline Lafontaine-Dosogne, L'évolution du programme décoratif des églises de 1071 à 1261, Actes XVe Congrès International d'études byzantines (Athènes 1976), I. Art et Archéologie, 1979, p. 309. On the conjunction of St.

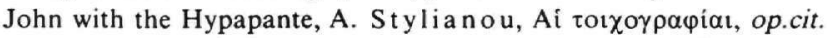
(note 5), p. 461. Stylia nou, The Painted Churches, op.cit. (note 4), p. 164-166. A characteristic feature of the layout of the programme is the conjunction of the representations in a sophisticated manner, Hadermann-Misguich, op.cit., p. 257. Lafontaine-Dosogne, op.cit., p. 315. H. Maguire, The Iconography of Symeon with the Christ Child in Byzantine Art, DOP 34-35 (1980-81), p. 269, figs 10-11. 


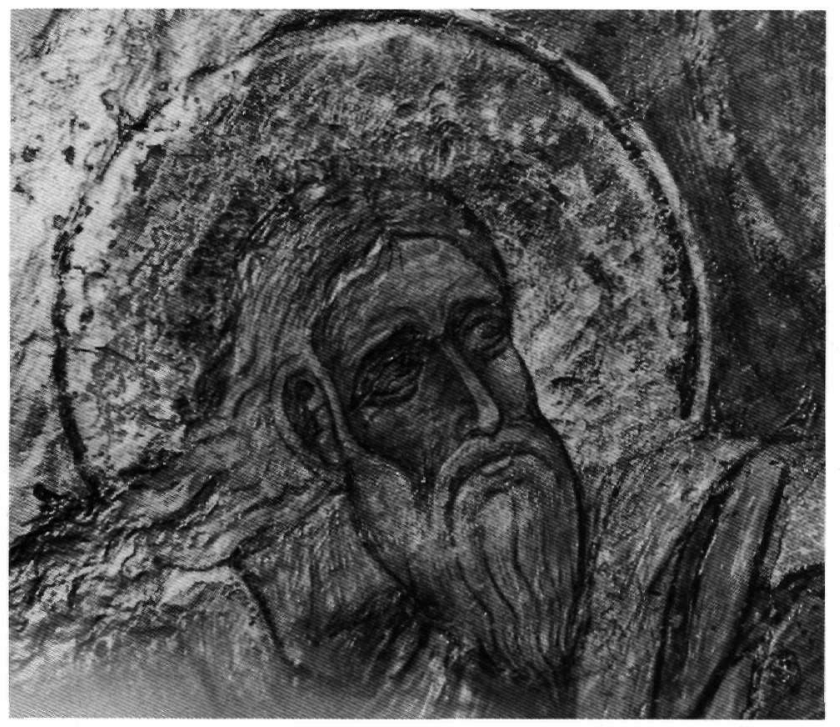

Fig. 11. Hermitage of Saint Neophytos. The Anastasis, detail: head of Adam.

of the models which the painter was familiar with or one of the sketches he had ${ }^{35}$ and proposed to the sponsor. On his own initiative or, possibly, according to the patron's wishes, the painter added the favourite epithet in Cyprus of the Virgin, "Eleousa".

The representation of the Annunciation which has survived in both monuments, follows the usual disposition $^{36}$ but is combined with the depiction of ChristEmmanuel, who has been placed in both cases between the two basic figures, the Angel and the Virgin. In the church of Saint Neophytos, however, where the representation has been placed in the bema ${ }^{37}$ above the entrance to the cell, the Virgin (Fig. 7) is depicted seated on the left with her head turned in the opposite direction towards the Angel, approaching with a lively movement. Between them is the full-figure Christ-Emmanuel in a rectangular frame. He is depicted frontally and standing on a cushion of royal purple.

It is interesting to observe that in this case the painter, Theodore Apseudes, has adapted the scene to the surfaces at his disposal. He continued, however, to follow the current convention of leaving a space between the two figures, as befits the natural and spiritual distance between Mary and Gabriel ${ }^{38}$. The placing, also, of the Virgin to the left, at that time, shows the intent of the artist to adapt the representation to the space available to it, so that Mary is turned towards the Altar, which is the direction the archangel is coming from ${ }^{39}$.

In the church of the Panagia tou Araka at Lagoudera, the Annunciation has been placed on the eastern pendentives. The archangel, to the left, in a rush of motion,

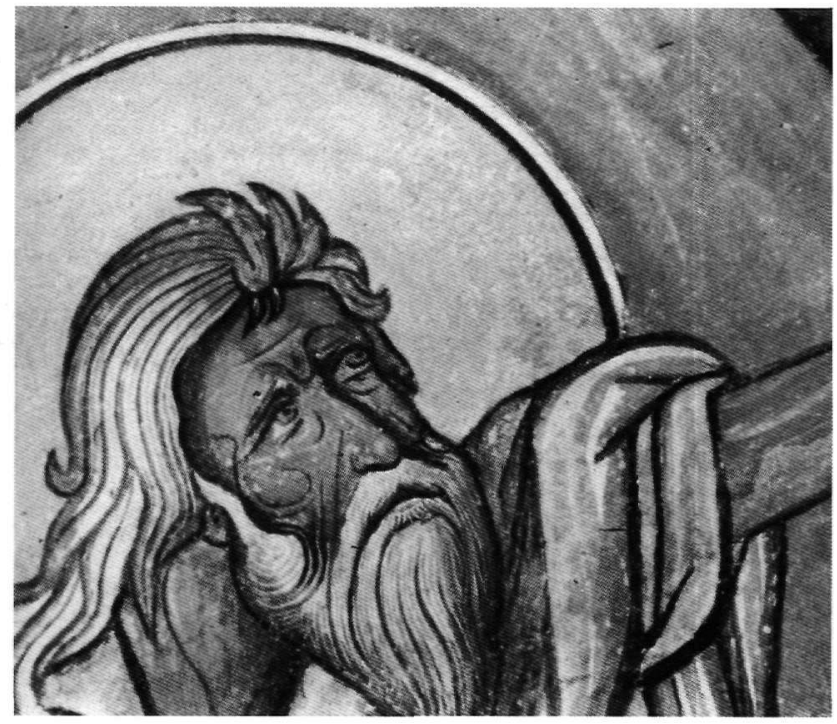

Fig. 12. Lagoudera. Panagia tou Araka. The Anastasis, detail: head of Adam.

is approaching the Virgin, on the right, who is seated with her head turned towards him. Both figures are depicted in front of multistoreyed edifices ${ }^{40}$. Between them, on the eastern section of the dome, is depicted Christ-Emmanuel, within a purple medallion. In this monument, too, the placing of the representation in the pendentives shows a flexibility in adaptation to space. It would seem, in fact, that the painter, on his own initiative - although it cannot be excluded that the wishes of the patron played a part - is following a local custom, since this has also been adopted in another well-known monument in Cyprus, that of the church of the Holy Apostles at Perahorio (1170-1180 AC) ${ }^{41}$.

The conjunction, however, of the Annunciation with the depiction of Christ-Emmanuel, which emphasizes the fact of the Incarnation of the $\operatorname{Logos}^{42}$, constitutes an interesting example characterizing both monuments. It is worth noting that while, from the 12th century on, this scene often co-exists with various subjects in which the representations' epiphanic character is stressed ${ }^{43}$, the figure of Christ-Emmanuel is familiar from the front of the apse of the church of the Holy Sepulchre ${ }^{44}$. The above combination, which shows a good knowledge and easy use of the semantic content of the iconographical "vocabulary", may reflect the personal wish of Saint Neophytos, since he would have known of this representation from his visit to the Holy Land. In fact, the painter seems to have also used the same composition in the church of the Panagia tou Araka, as he was familiar with it from the decoration of the bema of the hermitage of Saint Neophytos, where he first painted it. He succes- 
fully adapted the ensemble moreover, in both cases, to the available space. It is actually worthy of notice that this combination is found in both Cypriot monuments, and is unknown elsewhere, although it successfully renders the semantic message of the composition, according to the demands of the time.

In the representation of the Anastasis (Descent into Hell) which has also survived in both monuments, the painter seems to have used the same models (Figs 11, $12)$, which he adapted to entirely different spaces ${ }^{45}$.

35. Papadopoulos-Kerameus, op.cit. (note 27). M. Chatzidakis,

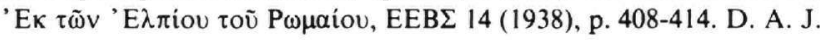
Ross, A Late Twelfth Century Artist's Pattern Sheet, JWarb 25 (1962), p. 122ff. K. S nipes, A Preliminary Study of the Yale Menologium Pattern Sheets, The Yale University Library Gazette 42 (1968), p. 140-153. W. Cahn- J. Marrow, Medieval and Renaissance Manuscripts at Yale, A Selection, Yale University Library Gazette 52 (1978), p. 273-274. H. B u cht hal, The "Musterbuch" of Wolfenbüttel and its Position in the Art of the Thirteenth Century, Vienna 1979, p. 13-15. Concerning the post-Byzantine period, Laskarina Bou-

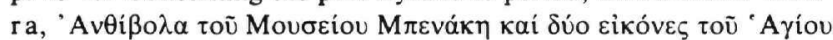

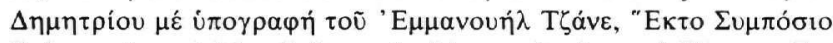

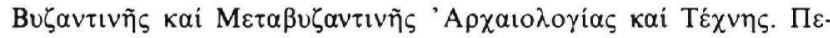

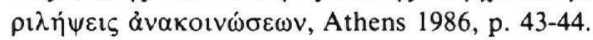

36. G. Millet, Recherches sur l'iconographie de l'évangile aux XIVe, XVe et XVIe siècles d'après les monuments de Mistra, de la Macédoine et du Mont-Athos, Paris 1960², p. 67-92.

37. Originally it must have also included the naos.

38. O. Dem us, Byzantine Mosaic Decoration. Aspects of Monumental Art in Byzantium, London $1953^{2}$, p. 23.

39. Millet, op.cit., p. 69 , on a place near the Altar. E. Kitzinger, The Mosaics of the Capella Palatina in Palermo. An Essay on the Choice and Arrangement of Subjects, ArtB 31 (1949), p. 277.

40. As an example of the painter's manneristic development, according to the stylistic trends of his period, Me gaw, Background Architecture, op.cit. (note 5).

41. On the Holy Apostles, see supra, note 24. Cf. also, Ha de r ma n nM is guich, Kurbinovo, op.cit. (note 32), p. 97-98, n. 224; Lafontaine-Dosogne, op.cit. (note 34), p. 312-313.

42. Isaias, 7, 14. A. Grabar, L'Iconoclasme byzantin. Le dossier archéologique, Paris $1984^{2}$, p. 266. Jane Timken-Mathews, The Pantocrator: Title and Image, New York University Ph. D., 1976, p. 60-62.

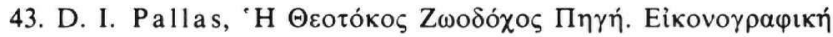

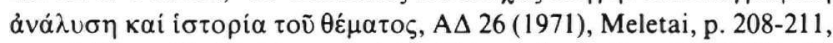

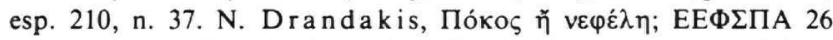
(1977-1978), p. 261. Lafontaine-Dosogne, op.cit. (note 34), p. 313 , n. 73. Theodora Iliopoulou-Rogan, Quelques fresques caractéristiques des églises byzantines du Magne, Actes XVe Congrès International d'études byzantines (Athènes 1976), Art et Archéologie, IIA, 1981, p. 208-216. E. Kitzinger, The Descent of the Dove. Observations on the Mosaic of the Annunciation in the Capella Palatina in Palermo, in: Irmgard Hutter (ed.), op.cit. (note 33), p. 114-115. Anastasia Koumoussi, Les peintures murales de la Transfigura-

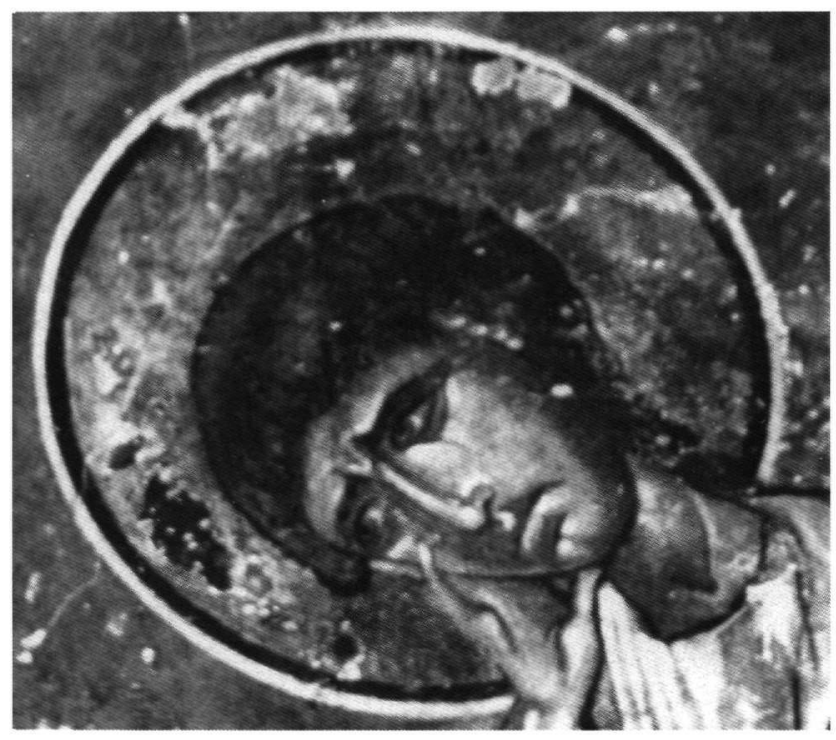

Fig. 13. Hermitage of Saint Neophytos. The Crucifixion, detail: head of Saint John.

Fig. 14. Lagoudera, Panagia tou Araka. Saint Peter, detail.

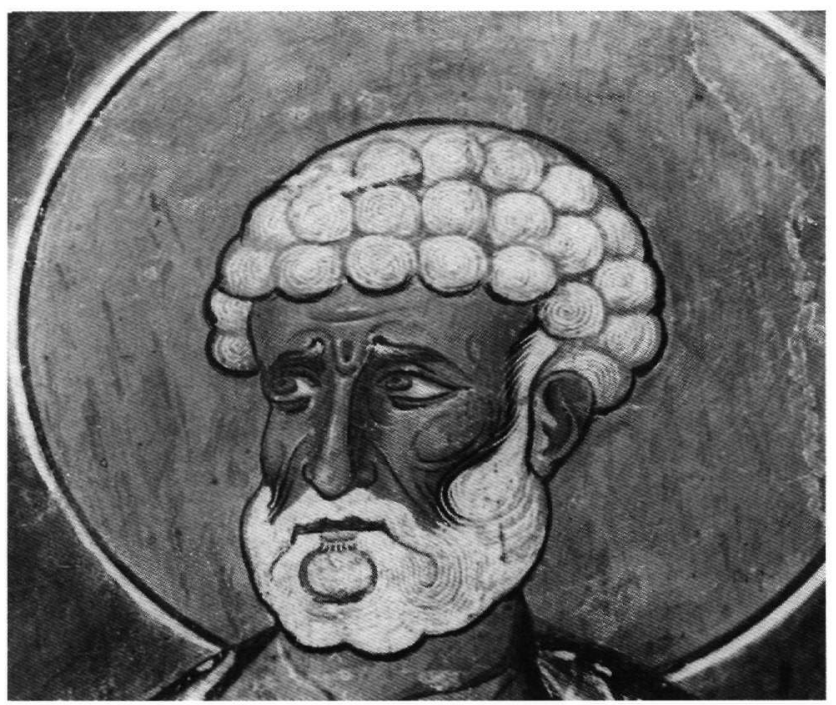

tion de Pyrgi et de Sainte-Thècle en Eubée (Rapports avec l'art occi-

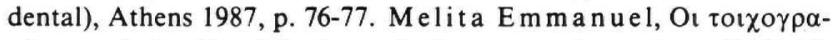

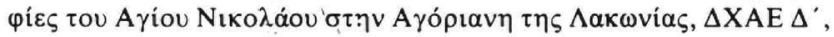
I $\Delta^{\prime}(1987-1988)$, p. 133-134.

44. H. Vincent - F. M. A bel, Jérusalem nouvelle, II, Paris 1914, I, p. 261. Wharton-Epstein, Formulas, op.cit. (note 11), p. 398. Ead., Art of Empire, op.cit. (note 10), p. 89. It is worthy of notice that the icon of the Virgin at Saint Neophytos' iconostasis is decorated with a zig-zag pattern that is preserved in the transept mosaics in the Basilica of the Nativity, at Bethlehem, Weyl Carr - Morrocco, op.cit. (note 22), p. 108.

45. Hadermann-Misguich, op.cit. (note 32), p. 165. A. Papa-

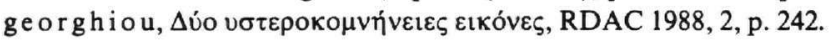


However, the rich landscape, rendered with curved lines and ochra shadings in the church of the Panagia tou Araka, reveals the manneristic development of the artist's work. The same applies to the scene of the Ascension, which has also survived in both monuments. On the ceiling of the bema of the hermitage of Saint Neophytos, against a blue field, the Virgin prays, turned in a three-quarters view towards Christ, while the angel is depicted in the centre, in frontal view. On the right and left, the groups of Apostles are placed separately in a rounded ochre-coloured landscape (Fig. 9), suggesting the earthly globe ${ }^{46}$. In the barrel-vault of the bema of the church of the Panagia tou Araka, the scene has been disposed in two groups, with the frontal figures, that of the Virgin in the southern section and that of the Angel in the northern section, occupying the centre (Fig. 10). In this depiction, it is interesting to see the manner in which colour has been used. The green ground on which the figures stand constitutes the background in the entire western section of the scene while, in the eastern section - which is near the Altar - the field is blue, in an extreme expression of the painter's chromatic mannerism. It may thus reflect the same theoretical dimension, as in the representation of the previous monument, suggesting the realisation of the Event between earth and heaven.

As regards the choice of the saints depicted in the two churches, the absence of any female figure, apart from that of Saint Mary of Egypt, in the church of the Panagia tou Araka, is worth noting ${ }^{47}$. In the case of the Enkleistra and of the bema of Saint Neophytos, this omission is in accord with the personality and the views of the patron, since it is known that he had not only banned women from visiting the monastery but had also banned all female animals ${ }^{48}$. As regards Lagoudera, however, the fact that the western wall of the church - where the depiction of female figures is usual in churches without a narthe $\mathrm{x}^{49}-$ has been destroyed, weakens the above observation. However, if there was omission ${ }^{50}$, it seems very likely that it was due to the painter's own initiative. He may have been a monk himself at the time when he was executing the murals of the Araka church. It seems certain that it was not the patron's wish; his personality, as we have seen, would not be concordant with such prejudices.

A similar indication is the stress laid on the depictions of monks in the same monument ${ }^{51}$. Only they, together with Peter and Paul, are portrayed full-figured and with open, inscribed scrolls, in prominent positions, on the western pilasters and the western bays of the naos. In view of the fact that this choice does not seem to agree with the character and education of the patron, it must be attributed to the artist who, at a younger age, had painted the Enkleistra and the bema of Saint Neophytos and who, may have become a monk himself by this time.

According to the above, then, certain interesting ideas may perhaps be formulated, based on a number of common representations in these two groups of murals of the late 12th century, whose patrons were men of different social background and education. As a matter of fact they represent different social groups, the one being a member of the monastic community and the other belonging to the laity. To begin with, it is important to note that both the above patrons employed the same excellent artist, who expressed himself stylistically in exactly the same way in both works. This fact, which constitutes evidence that stylistic similarity in works of art does not necessarily indicate identical social class of the patronage or vice versa ${ }^{52}$ suggests corresponding economic possibilities of the two donors ${ }^{53}$.

In addition, as is apparent in both monuments, the intervention of the patron was determinative in the arrangement in general terms, of the content of the iconographical programme. However, it becomes evident that the initiatives of Saint Neophytos are more substantial - although he may not be the sponsor - than the contribution of the archon, Leon Authentes, both in the choice of the particular figures and in the formulation of the iconographical vocabulary, according to the semantic content of certain representations. Nonetheless, the role of the painter in this domain does not seem insignificant, since he also intervenes in the choice of certain representations.

Thus, at the Enkleistra and the bema of the hermitage of Saint Neophytos, the whole content of the decoration, as well as the accompanying inscriptions, which must be attributed to the patron, are animated by his hope of future salvation and his establishment in paradise. On the contrary, in the church of the Panagia tou Araka, as the surviving inscriptions also reveal, the donor prays not only for future salvation but also for earthly happiness during the remainder of his life, together with that of his wife and his children.

In order, however, to formulate his own personal prayer which receives the favourable response of the Christ, Saint Neophytos chooses the representation of the Virgin and Child, holding an open scroll, where an unusual prayer is addressed to the Christ-Child, who responds favourably. In the case of the church of the Panagia tou Araka, however, on the same particular theme, Leon seems to have accepted the iconographical type which was usual at the time, and which must have been proposed by the painter, since it would have been included 
in the subject matter of the models that he brought with him. The conjunction, also, of the Christ-Emmanuel with the representation of the Annunciation, which was suggested by Saint Neophytos for the decoration of the bema at his monastery, inspired the painter who executed it on his own initiative in the church of the Panagia tou Araka as well, influenced as he was by his work on the murals of the bema in the hermitage of Saint Neophytos.

The emphasis, furthermore, on figures of monks in the programme of the church of the Panagia tou Araka, constitutes yet another indication of the further theoretical contribution of the painter in the artistic process. The differentiation of the landscape in the depiction of the Ascension, in the bema of the church of Saint Neophytos, also seems to be due to a personal intervention of the painter, reflected also in the church of Lagoudera. According to the above, therefore, and considering that the theoretical contribution of the painter had been clearly traced, along with the patron's intervention, and that there existed, therefore, a dialectical relationship between them, it is particularly interesting to note that the artist left his name on the Enkleistra of Saint Neophytos and perhaps also in the church of the Panagia tou Araka at Lagoudera. It becomes obvious, thus, that Theodore Apseudes was fully aware of his contribution, which he dared express discreetly with the means available to him at the time; and this, during a period of reshufflings, such as was the 12th century, during which a class consciousness began to make its appearance among professional groups ${ }^{54}$. From this point of view it is worth noting that a change concerning the artist's position in society can also be traced, during the late mediaeval period in Western Europe ${ }^{55}$. In Byzantium, somewhat earlier than Theodore Apseudes, in AD 1169, the mosaicist Ephraim also left his name in the Basilica at Bethlehem ${ }^{56}$. We also have the name of the famous

46. The Mount of Olive Trees, Actions I, 12, N. Giolès, 'H

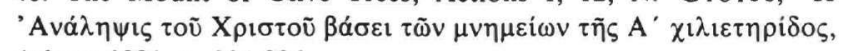
Athens 1981, p. 334-336.

47. Lafontaine-Dosogne, op.cit. (note 34), p. 317 , n. 86.

48. Т

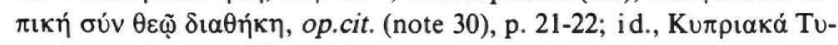
$\pi \mathrm{k \alpha}$, op.cit. (note 12), p. 89.

49. La fontaine-Dosogne, op.cit. (note 34), p. 317. At the Holy Apostles, Perachorio, a female head survives in the west bay, $\mathrm{Me}$ gaw-Hawkins, op.cit. (note 24), p. 290. At Saint Nicholas Kasnitzis, Kastoria (1170-1180) and at Agioi Anargyroi (1180-1190), the female saints are represented in the narthex ( T at ia na Malmquist, Byzan- tine 12th Century Frescoes in Kastoria, Agioi Anargyroi and Agios Nikolaos tou Kasnitzi, Uppsala 1979, p. 19, 25, 91), at Saint George, Kurbinovo (1191), the female saints are represented in the west wall (Haderma n -Misguich, op.cit. (note 32), sch. 3-4). In the church of the Evangelistria at Geraki, Peloponnese (ca 1200), there are representations of female saints in the northwest bay (N. K. Moutso-

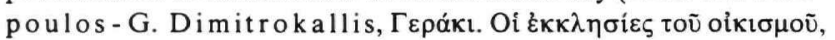
Thessalonica 1981, p. 91-92), on the date: Doula Mouriki, Stylistic Trends in Monumental Painting of Greece During the Eleventh and Twelf th Centuries, DOP 34 (1982), p. 113; Pan a y t id i, op.cit. (note 25), p. 470. In the chapel of the Virgin at the Monastery of Saint John the Theologian on Patmos there are no representations of female

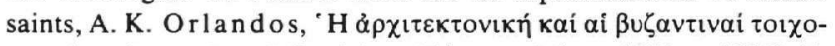

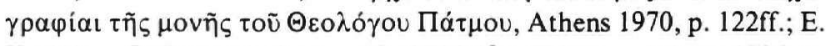

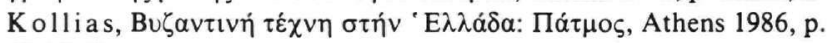

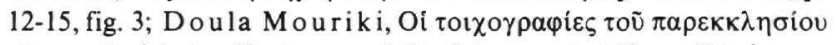

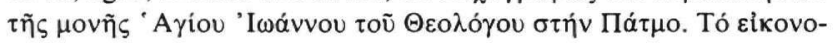

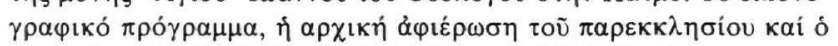

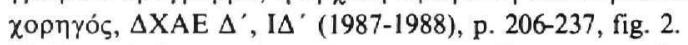

50 . The missing part is not large, A. Stylia nou, op.cit. (note 5), fig. 2; Stylianou, The Painted Churches, op.cit. (note 4), fig. 99.

51. Cf. the layout of the hermitage and the Bema of the church founded by Saint Neophytos, Man go-H awkins, op.cit. (note 4), p. 140ff.; Cor ma ck, op.cit. (note 11), p. 244-245; cf. also the iconographic programme of the chapel of the Panagia at the monastery of Saint John the Theologian, Patmos, supra, note 49.

52. On the opinion that spiritual conceptions of social classes are reflected in the stylistic trends, V. D ju ri ć, La peinture murale byzantine, XIIe et XIIIe siècles, Actes XVe Congrès International d'études byzantines (Athènes 1976), Art et Archéologie, I, 1979, p. 159ff., esp. 165-166.

53. On the financial conditions of an agreement between donor and painter in the later Cretan society, during the Venetian occupation,

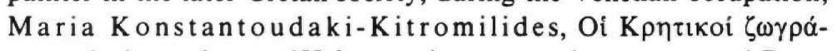

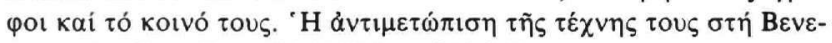

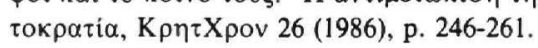

54. N. S voronos, IEE $\Theta^{\prime}$, p. 67-68. It is very interesting that during the late 13th century, the painters Michael Astrapas and Eutychios not only signed their work but also included the figures of their eponymous saints in the Bema, Cv. Grosdanov, Sv. Michailo i sv. Eutihije u crkvi sv. Bogorodice Perivlepte, Zograf 3 (1969), p. 11-12. During the 13 th century, many more signatures of painters are preserved, Kalopissi-Verti, op.cit. (note 3). On the place of the painter in the Cretan society, during the 15 th and 16th centuries, under the Venetian occupation, Konstantoudaki-Kitromilides, op.cit., p. $252-255$.

55. Xénia Muratova, Vir guidem fallax et falsidicus, sed artifex praeelectus. Remarques sur l'image sociale et littéraire de l'artiste au moyen âge, in X. Barral I Altet (ed.), op.cit. (note 3), I, 1986, p. 53-72, esp. 61-62, 70-72.

56. W. Harvey - W. R. Lethaby - O. M. Dalton - H. A. A. Cruso-A. C. Headla m, The Church of the Nativity at Bethlehem, London 1910, p. 43-51, esp. 43, fig. 27. H. Vincent - F. M. Abel, Bethléem. Le sanctuaire de la Nativité, Paris 1914, p. 157-159. P. Bellarmino Bagatti, o.f.m., Gli antichi edifici sacri di Betlémme, Jerusalem 1952, p. 58-68, esp. 60. V. Tza fe ris, The Wall Mosaics in the Church of the Nativity, Bethlehem, Actes XVe Congrès International d'études byzantines (Athènes 1976), Art et Archéologie, IIB, 1981 , p. $891 \mathrm{ff}$., esp. 900 . A. Cutler, Ephraim, Mosaicist of Bethlehem: The Evidence from Jerusalem, JArt 12-13 (1986-1987), p. 179183. G. K ühnel, Wall Painting in the Latin Kingdom of Jerusalem, Berlin 1988, p. 1ff., esp. 5, fig. 2. 
Eulalios, who, during the years of the rule of Manuel Comnenus (1143-1180 AC) renewed the mosaic decoration of the church of the Holy Apostles and, in fact, included his self-portrait in a Biblical scene ${ }^{57}$. It is equally interesting that, in both monuments of Cyprus, the donors have also very clearly left traces of their own personalities $^{58}$. The personal intervention, however, of the monk Neophytos with his lowly religious education $^{59}$, seems to be greater than that of Leon Authentes, whose anthropocentric - to a degree - view of life, within the framework, naturally, of the mediaeval world, did not give him the prerequisites nor the selfconfidence necessary to impose intensely personal initiatives $^{60}$ in the formulation of the iconographical "vocabulary" of the church he founded ${ }^{61}$.

57. Mango, op.cit. (note 2), p. 229-233.

58. Cf. Cormack, op.cit. (note 11), p. 229. Oikonomidès, op.cit: (note 3), p. 49-50. An analogous phenomenon is the appearance of donor portraits, Svetlana Tomeković-Reggiani, Portraits et structures sociales au XIIe siècle. Un aspect du problème: le portrait laïque, Actes XVe Congrès International d'études byzantines (Athènes 1976), Art et Archéologie, IIB 1981, p. 823-836.

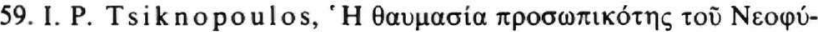

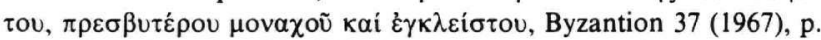

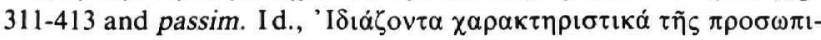

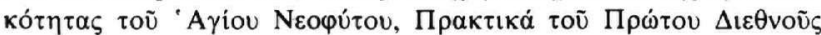

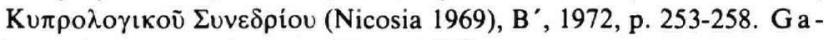
lat a rio to u, op.cit. (note 11), p. 168ff.

60 . In another period (14th century) a very important personality with high humanistic culture, Theodore Metochites, dictated not only the layout but also the vocabulary of the iconographic programme of the parecclesion, the funerary chapel he founded, P. A. Underwood (ed.), The Kariye Djami, New York 1966, 1, p. 192ff; 3, pls 335ff.; I. Ševč en k o, Theodore Metochites, The Chora, and the Intellectual Trends of His Time, in: P. A. Underwood (ed.), ibid., 4, Princeton 1975, p. $17 \mathrm{ff}$.

61. As has been mentioned before the entire layout of the programme is not examined, because this supposes a general examination of the two ensembles.

For the English translation I am indebted to Daphne Kapsambeli. 